\title{
Polemika z Żydami i judaizmem w Ad Quirinum (liber primus) Cypriana z Kartaginy
}

\section{Wstęp}

Wraz z rozwojem badań biblijnych i patrystycznych w XX wieku zarówno bibliści, jak też patrologowie zajmujący się badaniami nad egzegezą Ojców Kościoła zauważyli, że chrześcijanie pierwszych wieków wykorzystywali te same fragmenty Starego Testamentu jako dicta probantia w celu wykazania mesjańskości Jezusa, Jego bóstwa, zapowiedzi Kościoła jako nowego Izraela itp. Ponieważ zauważono, że te same zbiory cytatów starotestamentalnych pojawiają się zarówno w pismach Nowego Testamentu, jak też $\mathrm{w}$ tekstach patrystycznych, badacze wysnuli przypuszczenie, iż prawdopodobnie istniał $\mathrm{w}$ pierwszych wiekach naszej ery zbiór $\mathrm{w}$ formie księgi takich cytatów, które nazwano Testimonia. Początek dali mu prawdopodobnie chrześcijanie pochodzenia żydowskiego wykorzystujący go w dyskusji ze swoimi rodakami, którzy nie uznawali Jezusa za obiecanego Mesjasza ani tym bardziej za Syna Bożego, a wspólnoty Jego uczniów, Kościoła, za nowy Izrael. Wielkie zasługi w badaniach nad Testimonia położył Rendel Harris, który opublikował swoje wnioski w dwóch tomach². Niektórzy uczeni podjęli ten wątek badań, koncentrując się na konkretnych tekstach patrystycznych, by wykazać używanie przez nich Testimonia judeo-chrześcijańskich w polemice z Żydami. Prigent uczynił tak dla Listu Barnaby, wykazując, że autor nie cytował bezpośrednio tekstu biblijnego

Ks. prof. dr hab. Leszek Misiarczyk, kierownik Zakładu Badań na Historią Kościoła w Starożytności w Instytucie Nauk Historycznych na Wydziale Nauk Historycznych i Społecznych Uniwersytetu Kardynała Stefana Wyszyńskiego w Warszawie; email: 1.misiarczyk@uksw.edu.pl, ORCID: 0000-0002-9511-6174.

2 Por. J. Rendel Harris, Testimonies, t. 1-2, Cambridge 1916-1920. 
Starego Testamentu, ale czynił to z jakiegoś zbioru Testimonia, gdyż powielał nawet te same błędy ${ }^{3}$. Struktura Dialogu z Żydem Tryfonem Justyna Męczennika potwierdza również hipotezę, według której Testimonia skupiałyby się wokół następujących tematów w polemice z judaizmem: kult/ Prawo Mojżeszowe, Jezus Mesjaszem, Synem Bożym i chrześcijanie jako nowy lud wybrany ${ }^{4}$. Inni uczeni wyrażali swoje wątpliwości co do istnienia księgi Testimonia, gdyż, jak przekonywano, nie zachował się do naszych czasów żaden zbiór tego typu tekstów biblijnych z II wieku. Słusznie zauważono jednak, że Testimonia w formie księgi pojawia się wśród pism Cypriana z Kartaginy w połowie III wieku i Grzegorza z Nyssy w IV wieku. W tekstach zaś z II wieku, takich jak wspomniane już wcześniej List Barnaby i Dialog Justyna, znajdujemy te same teksty starotestamentalne używane w argumentacji chrystologicznej, które odbiegają od tekstu biblijnego, powtarzając niekiedy wręcz te same błędy, co wskazuje na ich przejęcie z jakiegoś innego źródła spisanego, a nie z tradycji ustnej. Wygląda więc na to, że już pod koniec I i na początku II wieku w środowisku judeo-chrześcijan powstały pierwsze zbiory owych Testimonia, czyli cytatów z ksiąg Starego Testamentu używanych przez nich w dyskusjach z wyznawcami judaizmu, aby ich przekonać do chrześcijaństwa. Początkowo zapewne te zbiory były niewielkie i przekazywano je ustnie, z czasem jednak zaczęły się rozrastać, gdyż dołączano do nich nowe fragmenty i pojawiła się potrzeba ich spisania. Proces spisywania przyspieszyło również używanie tych tekstów w polemice $\mathrm{z}$ Żydami przez chrześcijan pochodzenia pogańskiego, którzy nie znali tak dobrze Starego Testamentu i potrzebowali posiadać odpowiednie cytaty w formie spisanej ${ }^{5}$. Nie wiemy, czy w II wieku te cytaty funkcjonowały w formie księgi czy w formie ustnej albo tylko zbiorów spisanych na pojedynczych kartach. Nie posiadamy żadnego świadectwa istnienia takich ksiąg w tym okresie, więc raczej druga hipoteza wydaje się bardziej prawdopodobna. W połowie III wieku natomiast Testimonia pojawiają się już w formie księgi, czego dowodem

3 Por. P. Prigent, Les Testimonia dans le Christianisme primitive. L'Épitre de Barnabé I-XVI et ses source, Paris 1961. Zob. także: A. O’Hagan, Early Christian Exegesis exemplified from the Epistle of Barnabas, „Australian Biblical Review” 11 (1963) s. 33-40; S. Lowy, The Confutation of Judaism in the Epistle of Barnabas, ,Journal of Jewish Studies” 11 (1960) s. 1-33; A.R. Kraft, Barnabas 'Isaiah Text and ,, The Testimony Book” Hypothesis, ,Journal of Biblical Literature” 79 (1960) s. 336-350.

4 Por. H. Chadwick, Justin Martyr's Defence of Christianity, „John Ryands Library” 47 (1965) s. 275-297; L. Misiarczyk, Il Midrash nel Dialogo con Trifone di Giustino Martire, Płock 1999.

5 Por. M.Ch. Albl, „And Scripture cannot Be Broken”. Function of the Early Christians Testimonial Collections. NTSup 96, Leiden 1999. 
jest traktat Cypriana z Kartaginy Ad Quirinum, którego szczegółową analizą zajmę się w dalszej części.

Niniejsze studium stawia sobie zatem następujący zasadniczy cel: rekonstrukcja polemiki Cypriana z Żydami i judaizmem w księdze pierwszej dzieła Ad Quirinum. Nie można jednak tego dokonać bez syntetycznego przedstawienia struktury pisma, czasu i miejsca jego powstania oraz adresata. Wstępna analiza pokazuje, że dzieło Cypriana zdecydowanie odbiega od znanych nam wcześniejszych zbiorów Testimonia z II wieku, jest bardziej obszerne i skupia cytaty biblijne wokół wielu różnych tematów. Tematyka polemiki z judaizmem w piśmie biskupa Kartaginy bardzo ściśle łączy się z kwestią obecności diaspory żydowskiej w Kartaginie i całej Afryce Północnej oraz relacjami chrześcijańsko-żydowskimi w regionie. Ważne więc będzie ustalenie, czy traktat Cypriana wpisuje się w realną polemikę i rywalizację religijną pomiędzy chrześcijanami a Żydami w Afryce Prokonsularnej w III wieku czy też jest raczej dziełem powstałym na użytek całego Kościoła, by dostarczyć chrześcijanom argumentów biblijnych w dyskusjach z wyznawcami judaizmu.

\section{Traktat Cypriana, jego adresat i struktura}

Dzieło Cypriana zostało wydane przez Gulielma Hartla w 1868 roku w serii Corpus Christianorum Ecclesiasticorum Latinorum (t. 3 ) i nosi tytuł Thasci Caecili Cypriani Ad Quirinum, (Testimoniorum libri tres) w edycji Migne'a natomiast - Testimoniorum libri tres Adversus Judaeos, gdzie wyraźnie podkreślono jego antyżydowski charakter. Nie jest to do końca prawdą, gdyż tylko księga I stanowi polemikę z judaizmem, w II księdze zaś autor starał się wykazać, że Jezus jest obiecanym Mesjaszem, księga III natomiast dotyczy już typowo chrześcijańskich tematów jak cnoty chrześcijańskie. Traktat ten łącznie z innym dziełem Cypriana Ad Fortunatum jest tekstem, który najbardziej pozwala nam poznać wersję tekstu biblijnego używaną w Afryce Północnej w jego czasach ${ }^{6}$. Dzieło jest bowiem zbiorem fragmentów z Pisma Świętego zebranych wokół bardzo konkretnych tematów.

6 Por. W. Hartl, Thasci Caecyli Cypriani Ad Quirinium, (Testimoniorum libri tres), CSEL 3, Vindobonae 1868, s. 33-184; Cyprian, Do Kwiryna (Świadectw trzy księgi), tł. J. Czuj, POK 19, Poznań 1937, s. 113-134. Tłumaczenie polskie obejmuje jednak tylko tytuły bez tekstu biblijnego, zresztą słusznie, bo nie miałoby sensu tłumaczenie na język polski wersji tekstu biblijnego używanego w Afryce w połowie III wieku. 
Adresatem dzieła jest niejaki Kwiryniusz, którego Cyprian nazywa „umiłowanym synem” (filii charissime), ale to określenie należy oczywiście rozumieć w sensie szerokim. Nie chodzi o fizycznego syna Cypriana, ale raczej o jakiegoś chrześcijanina, który prosił go o wyjaśnienie ważnych kwestii. Cyprian podkreśla, że podjął się tego zadania, aby w dwóch księgach (libellos duos) wyjaśnić zasadnicze kwestie. Wygląda więc na to, że cały traktat liczył początkowo tylko dwie księgi, księga trzecia zaś została dodana później. Sam autor zaznacza zaraz na początku, że jego dzieło składa się z dwóch ksiąg, z których w pierwszej starał się wykazać, że Żydzi odeszli od Boga (a Deo recesisse) i stracili udzieloną im wcześniej i zapowiedzianą w przyszłości łaskę (ei indulgentiam Domini, quae sibi iam pridiem data et in posterum promissa fuerat, perdidisse). Chrześcijanie zaś zajęli ich miejsce i zasłużyli na łaskę Pana dzięki wierze w Niego, przychodząc ze wszystkich narodów i z całego świata (successisse vero in eorum locum Chrisitianos fide Dominum promerentes et de ominibus gentibus ac de toto orbe venientes). Druga księga zaś poświęcona jest wykazaniu tajemnic Chrystusa, który przyszedł, aby wypełnić to, co zostało zapowiedziane w Starym Testamencie, w sposób doskonały i co pozwalało Go rozpoznać oraz uznać za obiecanego Mesjasza i Zbawiciela.

Struktura traktatu jest podobna do pisma Ad Fortunatum. Pierwsza księga, która zwiera 24 tytuły, jest więc polemiką z judaizmem i Żydami, druga natomiast, zawierająca 30 tytułów, jest syntezą chrystologii północnoafrykańskiej ${ }^{7}$ Trzecia księga zaś rozpoczyna się wstępem, który wyjaśnia, że Cyprian napisał ją na późniejszą prośbę Kwiriniusza i jest zbiorem zasad moralnych oraz dyscyplinarnych, a także swego rodzaju przewodnikiem w praktykowaniu cnót chrześcijańskich. Autor księgi wymienia ich 120, opierając się na odpowiednich fragmentach z Pisma Świętego. Ponieważ we wstępie do trzeciej księgi nie wspomina się w ogóle o pierwszych dwóch księgach, bardzo trudno jest rozstrzygnąć, czy połączenie wszystkich trzech ksiąg miało miejsce jeszcze za życia Cypriana czy też już po jego śmieci. Milczenie o dwóch pierwszych księgach zdaje się wskazywać na to, że raczej połączono je już po śmierci biskupa Kartaginy. Brakuje również szczegółowych danych, które pozwoliłyby na dokładną datację całego dzieła. Badacze sugerują, że ponieważ Cyprian używa trzeciej księgi w traktacie De habitu virginum, który datuje się na 249 rok, można przypuszczać, że Ad Quirinum powstałoby przed 249 rokiem ${ }^{8}$. Cyprian zapowiada, że zebrał jedynie nieliczne cytaty z Pisma Świętego dla tych, którzy dopiero rozpoczęli drogę wiary chrześcijańskiej. W miarę

Por. J. Quasten, Patrologia, t. 1, Casale Monferrato 1980, s. 593-594.

8 Por. A.L. Wiliams, Adversus Judaeos, Cambridge 1935, s. 56-64; J.P. Audet, L'Hypothese des Testimonia, „Revue Biblique” 70 (1963) s. 381-405. 
jednak wzrastania w wierze powinni czytać całe Pismo Święte zarówno Starego, jak i Nowego Testamentu. Warto dodać, że jego dzieło wpłynęło bardzo mocno na późniejszych Ojców, którzy polemizowali z Żydami i judaizmem, takich jak: Pseudo-Cyprian, Kommodian, Laktancjusz, Lucyferiusz z Cagiliari, Hieronim, Pelagiusz i Augustyn.

Wcześniejsze zbiory Testimonia, potwierdzone np. w Dialogu Justyna, były skupione wokół trzech tematów: przejściowy charakter Prawa Mojżeszowego, Jezus Mesjaszem, Synem Bożym i chrześcijanie/Kościół jako nowy Izrael. Cyprian natomiast bardzo mocno rozbudowuje swój traktat, wprowadzając nowy schemat: księga pierwsza jest poświęcona polemice z Żydami i judaizmem, druga wykazuje, że Jezus jest obiecanym Mesjaszem i Synem Bożym, trzecia zaś dotyczy zasad moralnych życia chrześcijan, tematyka praktycznie nieobecna wcześniej w Testimonia. Biskup Kartaginy wprowadza nie tylko wiele nowych tytułów tematycznych, wokół których skupia teksty biblijne, ale również przytacza zdecydowanie więcej samych tekstów biblijnych na poparcie swojej tezy. Ponieważ niniejsze opracowanie ogranicza się tylko do księgi pierwszej, przedstawię teraz jedynie jej strukturę, pomijając księgę drugą i trzecią. Przedstawia się ona następująco:

1. Iudaeos in offensam Dei grauiter deliquisse, quod Dominum reliquerint et idola secuti sint (Ex. 32, 2; 32, 31sq.; Deut. 32,17; Iud. 2,11sq.; Mal. 2,11 sq.).

2. Quod prophetis non crediderint et eos interfecerint (Hier. 25,4 sq.; I Reg. 19,10; Esdra 1,2 sq.).

3. Ante praedictum, quod Dominum neque cognituri neque intellecturi neque recepturi essent (Es. 1,2 sq.; 6,9 sq.; Hier. 2,13; 6,10; Prov. 1,28sq.; Ps 27,4 sq.; Ps 81,5; Io 1,11sq.).

4. Quod scripturas sanctas intellecturi Iudaei non essent, intellegi autem haberent in nouissimis temporibus, posteaquam Christus uenisset (Es. 29,11.18; Hier. 23,20; Dan. 12,4.7; 1 Cor. 10,1; 2 Cor. 3,14 sq.; Luc. 24,44 sq.).

5. Nihil posse Iudaeos intellegere de scripturis, nisi prius crediderint in Christum (Es. 7,9; Io. 8,24; Ab. 2,4; Gen. 15,6; Gal. 3,6 sq.).

6. Quod Hierusalem perdituri essent et terram quam acceperant relicturi (Es. 1,7 sq.; Matth. 23,37 sq.).

7. Item quod essent amissuri lumen domini (Es. 1,7 sq.; Io. 1,9 sq.; 3,18 sq.).

8. Quod circumcisio prima carnalis euacuata sit et secunda spiritalis repromissa sit (Hier. 4,3 sq.; Deut. 30,6; Ios. 5,2; Col. 2,11).

9. Quod lex prior quae per Moysen data est cessatura esset (Es. 43,18sq.; Matth. 11,14). 
10. Quod lex noua dari haberet (Mich. 4,2 sq.; Es. 2,3 sq.; Matth. 17,5).

11. Quod dispositio alia et testamentum nouum dari haberet (Hier. 31,31 sq.).

12. Quod baptisma uetus cessaret et nouum inciperet (Es. 43,18 sq.; 48,21; Matth. 3,11; Io. 3,5 sq.).

13. Quod ingum uetus enacuaretur et ingum nounm daretur (Ps. 2,1 sq.; Matth. 11,28 sq.; Hier. 30,8 sq.).

14. Quod pastores ueteres cessaturi essent et noui inciperent (Ez 34,10 sq.; Hier 3,15; Hier. 31,10 sq.).

15. Quod domus et templum Dei Christus futurus esset et cessasset templum uetus et nouum inciperet (2 Sam. 7,4; 5,12-14.16; Matth. 24,2; Mc 14,58).

16. Quod sacrificium uetus enacuaretur et nouum celebraretur (Es. 1,11 sq.; Ps. 49,13 sq.; Ps. 49,23; Ps. 4,6; Mal. 1,10 sq.).

17. Quod sacerdotium uetus cessaret et nouus sacerdos ueniret qui in aeternum futurus esset (Ps. 109,3sq.; 1 Sam. 2,25 sq.).

18. Quod propheta alius sicut Moyses promissus sit, scilicet qui testamentum nouum daret et qui magis audiri deberet (Deut. 18,17sq.; Io. 5,39.40.45 sq.).

19. Quod duo populi praedicti sint, maior et minor, id est uetus Iudaeorum et nouus qui esset ex nobis futurus (Gen. 25,23; Os. 2,$25 ; 1,10)$.

20. Quod ecclesia quae prius sterilis fuerat plures filios habitura esset ex gentibus, quam quot synagoga ante habuisset (Es. 5,41sq.; 1 Sam. 2,5).

21. Quod gentes magis in Christum crediturae essent (Gen. 12,1 sq.; Gen. 27,27 sq.; (Gen. 48, 8-17; Num. 23,24; Deut. 28,44; Ez. 6,17 sq.; Ps. 17,44 sq.; Hier. 1,5; Es. 55,4 sq.; 11,10; 8,23; 9,1; 45,1; 66,18 sq.; 5,25 sq.; 52,15; 65,1; Act. 13,46 sq.).

22. Quod panem et calicem Christi et omnem gratiam eius amissuri essent Iudaei, nos uero accepturi, et quod christianorum nouum nomen benediceretur in terris (Es. 65,13.15 sq.; 5,26 sq.; 3,1; Ps. 33,9 sq.; Io. 6,35; 7,37 sq.; 6,53).

23. Quod ad regnum caelorum magis gentes quam Iudaei perueniant (Matth. 8,11 sq.).

24. Quod solo hoc Iudaei accipere ueniam possint delictorum suorum, si sanguinem Christi occisi baptismo eius abluerint et in ecclesiam transeuntes praeceptis eius obtemperauerint (Es. 1,14 sq.).

Jak wspomniałem wcześniej, Cyprian nie zachowuje sztywno schematu polemiki Justyna z wyznawcami judaizmu obecnej w jego Dialogu $z$ Żydem Tryfonem: charakter przejściowy Prawa Mojżeszowego, Jezus 
obiecanym Mesjaszem i Synem Bożym, chrześcijanie nowym Izraelem. W sensie szerokim można powiedzieć, że poświęca księgę pierwszą polemice z judaizmem, księgę drugą uzasadnieniu, że Jezus jest Synem Bożym, bo te argumenty przeważają tutaj, a nie Jego mesjańskość, w księdze trzeciej zaś już nawet nie wyjaśnia, że chrześcijanie są nowym ludem wybranym, ale przedstawia konkretne zasady życia chrześcijańskiego. Jeśli zaś chodzi o księgę pierwszą, to choćby po pobieżnej analizie tytułów w niej zawartych widzimy, że praktycznie wszystkie trzy motywy są w niej obecne i wymieszane między sobą. Na początku mamy więc, podobnie jak u Tertuliana, motyw ogólny przedstawienia Żydów jako tych, którzy odstąpili od kultu jedynego i prawdziwego Boga, czcząc bóstwa pogańskie (1) oraz nieuwierzyli zapowiedziom proroków i ich zabijali (2). Pozostałe tytuły przedstawione przez Cypriana dają się pogrupować według schemata Justyna:

- przejściwy charakter przepisów Prawa Mojżeszowego, które zostanie zastąpione nowym Prawem: Quod circumcisio prima carnalis euacuata sit et secunda spiritalis repromissa sit (8), Quod lex prior quae per Moysen data est cessatura esset (9), Quod lex noua dari haberet (10), Quod dispositio alia et testamentum nouum dari haberet (11), Quod baptisma uetus cessaret et nouum inciperet (12), Quod iugum uetus euacuaretur et ingum nouum daretur (13), Quod sacrificium uetus euacuaretur et nouum celebraretur (16);

- Chrystus nowym prorokiem i świątynią: Quod domus et templum Dei Christus futurus esset et cessasset templum uetus et nouum inciperet (15), Quod sacerdotium uetus cessaret et nouus sacerdos ueniret qui in aeternum futurus esset (17), Quod propheta alius sicut Moyses promissus sit, scilicet qui testamentum nouum daret et qui magis audiri deberet (18);

- chrześcijanie nowym ludem wybranym: Quod pastores ueteres cessaturi essent et noui inciperent (14), Quod duo populi praedicti sint, maior et minor, id est uetus Iudaeorum et nouus qui esset ex nobis futurus (19), Quod ecclesia quae prius sterilis fuerat plures filios habitura esset ex gentibus, quam quot synagoga ante habuisset (20), Quod gentes magis in Christum crediturae essent (21), Quod panem et calicem Christi et omnem gratiam eius amissuri essent Iudaei, nos uero accepturi, et quod christianorum nouum nomen benediceretur in terries (22), Quod ad regnum caelorum magis gentes quam Iudaei perueniant (23), Quod solo hoc Iudaei accipere ueniam possint delictorum suorum, si sanguinem Christi occisi baptismo eius abluerint et in ecclesiam transeuntes praeceptis eius obtemperauerint (24). 
Jak widzimy z powyższego zestawienia, najwięcej punktów dotyczy uzasadnienia charakteru przejściowego Prawa Mojżeszowego i przedstawienia chrześcijan jako nowego ludu wybranego w miejsce Żydów, najmniej zaś - tematu Chrystusa. Taki zabieg jest zrozumiały, jeśli pamiętamy, że chrystologii poświecona jest cała księga II traktatu. Choć nie pojawiają się tutaj żadne wyjaśnienia teologiczne, to pismo Cypriana ma ogromne znaczenie $\mathrm{w}$ badaniach nad rekonstrukcją tekstu biblijnego używanego w kościele północnoafrykańskim w III wieku przed Wulgatą Hieronima, czyli tzw. Vetus Latina albo lepiej Vetus Afra. Chcąc dokładnie zbadać tekst biblijny cytowany przez biskupa Kartaginy, trzeba by bardzo szczegółowo porównać każdy fragment tekstu łacińskiego, który cytuje, z krytyczną edycją Wulgaty Hieronima, co przekracza ramy niniejszego studium. Wstępnie i sondażowa analiza porównawcza prowadzi do wniosku, że tekst Pisma Świętego Starego i Nowego Testamentu cytowany przez Cypriana jest inny niż w Wulgacie Hieronima. Dzisiaj przeważa wśród uczonych przekonanie, że w tym okresie nie istniało żadne oficjalne tłumaczenie tekstu Pisma Świętego na język łaciński w Afryce Prokonsularnej. Choć na tym obszarze były w użyciu liczne wersje tekstu biblijnego, jedne bardzie akceptowane, inne mniej, to jednak brakuje dowodów na powszechną zgodę całego Kościoła północnoafrykańskiego na jedną wersję tekstu biblijnego. Praktycznie każda wspólnota posiadała swoją wersję Pisma Świętego9. Jednolitej wersji Pisma Świętego nie było również później w czasach Augustyna, który wspomina o licznych łacińskich tłumaczeniach używanych w różnych wspólnotach (De doctrna christiana II 11,16), sam zaś preferował rękopisy Vetus Itala przywiezione z Italiii ${ }^{10}$. Jeśli więc dzisiaj w badaniach używa się zwrotu Vetus Afra, to absolutnie nie można go rozumieć jako określenie jednej, aceptowanej przez wszystkich wersji tekstu biblijnego, ale raczej jako różnych wersji będących w obiegu w Afryce Prokonsularnej. Jeśli, jak zobaczymy dalej, pierwszymi chrześcijanami w Afryce byli najprawdopodobniej żydowscy emigranci z Palestyny, to niewykluczone, że pierwsze tłumaczenia Pisma Świętego na język łaciński zostałyby dokonane bezpośrednio z tekstu hebrajskiego, a nie z Septuaginy ${ }^{11}$. Rozbieżności z Wulgatą wskazują jednak, że byłaby to inna wersja tekstu hebrajskiego niż ta, z której korzystał Hieronim.

9 Por. R. Ferri, Regional Differentiation and the Old Latin Bible?, „Linguarum Varietas" 6 (2017) s. 255-261; H.A.G. Houghton, The Latin New Testament: A Guide to its Early History, Text and Manuscripts, Oxford 2016.

10 Por. F. Decret, Early Christianity in North Africa, Cambridge 2011, s. 30-31.

11 Takie zdania są wyrażone w: G. Quispel, The Discussion fo Judaic-Christianit. Additional Note, „Vetera Christianorum” 22 (1968) s. 81-93; J. Trebolle Barrera, Lo Christiano e lo Judio en la Vetus Latina, „El Olivo” 15 (1991) s. 123-141. B. Kedar 


\section{3. Źródla i kontekst historyczny powstania pisma}

Pytanie o inspiracje dla traktatu łączy się ściśle z kwestią dotyczącą kontekstu historycznego życia i działalności pisarskiej Cypriana. Wiemy z jednej strony, że biskup Kartaginy bardzo często korzystał z pism Tertualiana, stąd też wydaje się zasadne pytanie, na ile traktat Ad Quirinum zależy w formie literackiej i treści od jego Adversus Iudaeos. Czy dzieło Cypriana, jak też Tertuliana powstały jako odpowiedź na realne zagrożenie ze strony prozelityzmu żydowskiego w Afryce Prokonsularnej czy też powtarzają za wcześniejszymi pismami z gatunku Adversus Iudaeos stereotypy na temat Żydów i judaizmu? Jeśli chodzi o pierwszą kwestię, to, choć Cyprian w innych przypadkach odwoływał się wprost do pism Tertuliana, w traktacie Ad Quirinum brakuje jakiegokolwiek odniesienia do Adversus Iudaeos. To jednak nie przesądza jeszcze o niczym, gdyż Cyrpian mógł czerpać od Tertuliana, nic o tym nie wspominając. Porównanie obydwu traktatów nie potwierdza jednak zależności. Po pierwsze, rodzaj literacki jest zupełnie inny. Tertulian w swoim dziele prowadzi argumentację teologiczną, opierając się tylko na nielicznych tekstach biblijnych, Cyprian natomiast przytacza tylko same teksty biblijne bez jakiegokolwiek komentarza teologicznego. Po drugie, układ obu pism jest zasadniczo inny. Tertulian rozpoczyna swój wywód od zapowiedzi pojawienia się dwóch ludów (Rdz 25,23) i przekonuje, że młodszy lud, czyli chrześcijanie, mają panować nad starszym, czyli Żydami (Wj 32,23; 32,4.8), ponieważ Żydzi zaczęli czcić bogów pogańskich. Zarzut wobec Żydów, że porzucili kult jedynego Boga i zaczęli czcić bóstwa pogańskie, pojawia się, co prawda, zaraz na początku księgi pierwszej Ad Quirinum, ale już temtyka dwóch ludów, starszego i młodszego, pojawia się dalej i bez wzmianki, że młodszy, czyli chrześcijanie, będzie panował nad starszym, czyli Żydami. Dalej, według Tertuliana prawo naturalne istniało przed Prawem Mojżesza i zostało ono dane wszystkim narodom, obrzezanie zaś nie może być absolutnym warunkiem zabwienia, ponieważ Adam nie był obrzezany, a Abraham podobał się Bogu wcześniej, zanim został obrzezany i wcale nie obchodził szabatu. W dalszej części pisma Tertulian przytacza teksty biblijne, by wykazać, że Jezus jest obiecanym Mesjaszem, Cyprian natomiast poświęci tej tematyce całą księgę II swojego dzieła. Tertulian powtarza schemat Justyna: Prawo - Mesjasz - chrześcijanie nowym ludem wybranym, choć nie zawsze w takiej kolejności, Cyprian natomiast odchodzi od tego schematu na rzecz wielu szczegółowych kwestii. Warto jednak zauważyć, że rozdziały 9-14 są zgodne niemal dosłownie z fragmentami III księgi

(The Latin Translations, „Mikra” (1988) s. 299-338) zaś zauważa, że ślady wpływu tekstu hebrajskiego mogą być efektem późniejszych korekt. 
Adversus Marcionem ${ }^{12}$. Pewne ukryte inspiracje są widoczne, ale traktat Cypriana jest samodzielnym dziełem autora i został pomyślany jako zbiór krótkich wersetów biblijnych użytecznych w polemice z Żydami na określone tematy bez długich wywodów teologicznych. Może to wskazywać na sytuację, gdy polemika ze strony lokalnych Żydów stawała się coraz bardziej natarczywa i chrześcijanie, w tym Kwiriniusz, adresat pisma, prosili biskupa o konkretne narzędzia do walki z ich argumentami. Traktat Tertuliana był zbyt długi, by go używać w polemice. Wygląda więc na to, że zarówno traktat Teurtuliana, jak też dzieło Cypriana wpisuja się w kontekst rzeczywistej polemiki chrześcijan z Żydami w Afryce Prokonsularnej pod koniec II i w pierwszej połowie III wieku. Być może prozelici żydowscy mieli jakieś sukcesy w pozyskiwaniu dla judaizmu nieutwierdzonych w wierze chrześcijan kartagińskich lub pogan, stąd interwencja obu autorów. Czy jednak istaniało rzeczywiste zagrożenie dla wiary chrześcijańskiej ze strony Żydów w tym czasie i miejscu czy tylko Tertulian i Cyprian tak to postrzegali, reagując przesadnie lub uprzedzając zagrożenia? Jak łatwo się domyślić, dotykamy tutaj bardzo ważnej i nadal szeroko dyskutowanej kwestii obecności i statusu Żydów w Afryce Północnej na przełomie II i III wieku.

Choć nie istnieją żadne żydowskie teksty źródłowe pochodzące $\mathrm{z}$ tego regionu, to jednak inskrypcje i źródła chrześcijańskie z II wieku i późniejsze potwierdzają istnienie wspólnot judaistycznych w tym rejo$n^{13}{ }^{13}$. Można więc słusznie wnioskować, że Żydzi byli obecni w Afryce Północnej w okresie rzymskim już w I wieku i przypuszcza się, że przybyli tam jako emigranci z Palestyny lub Italii albo z Egiptu i Cyrenajki. $\mathrm{Z}$ badań materiału epigraficznego wynika, że należeli raczej do niższych warstw społecznych, choć niektórzy mogli być nawet średniozamożnymi mieszczanami ${ }^{14}$. Dowody na obecność diaspory żydowskiej

12 Por. Tertulian, Przeciw Żydom, tł. W. Myszor, w: Tertulian, Wybór pism II, PSP 29, Warszawa 1983, s. 182-218.

13 Por. H.Z. Hirschberg, A History of Jews in North Africa. I. From Antiquity to the Sixteenth Century, Leyde 1974; G. Camps, Réflexions sur l'origine des Juifs des régions nord-sahariennes, w: Communautés juives des marges sahariennes du Maghreb, ed. M. Abitbol, Paris 1982, s. 57-67; C. Gebbia, Le comunità giudaica nell'Africa romana antica e tardoantica, „L'Africa Romana” 3 (1986) s. 101-112. M. Hadas-Lebel, Les juifs en Afrique romaine, w: Questions d'histoire. L'Afrique romaine de 69 à 439. Romanisation et christianisation, red. B. Cabouret, Nantes 2005, s. 325-334; W. Horbury, Jewish and Christian Origins in Roman Africa, w: The Rise and Expansion of Christianity in the First Three Centuries of the Common Era, red. C.K. Rotschild - J. Schröter, Tübingen 2013, s. 51-69; S. Adamiak, Żydzi w Rzymskiej Afryce Pótnocnej, „Biblica et Patristica Thoruniensia” 7 (2014) s. 97-113.

14 Por. F. Decret, Early Christianity in North Africa, Cambridge 2011, s. 30-31. 
w Afryce znajdujemy w tekstach autorów chrześcijańskich pochodzących $\mathrm{z}$ tego regionu, takich jak traktaty Adversus Judaeos Tertuliana ${ }^{15}$ i pisma Augustyna (List 8$)^{16}$. Kodeksy Teodozjusza i Justyniana zawierają teksty, które wprost odnoszą się do Żydów afrykańskich albo mają z nimi jakiś związek, ale dotyczą okresu zdecydowanie późniejszego ${ }^{17}$. W drugiej połowie III wieku powiększają się znacząco skupiska ludzności żydowskiej w Kartaginie, Cyrcie, Sitifs i Auzie, a wykopaliska archeologiczne prowadzone w Tunezji, w Libii i Algerii potwierdziły ich obecność na tych terenach. Odkryto trzy synagogi: w Naro (dzisiejsze Hammam-Lif, Tunezja), Lepcis Magna, gdzie synagoga jest dołączona, co może wydawać się dziwne, do budynku rzymskiej bazyliki chrześcijańskiej w samej Kartaginie ${ }^{18}$, i w Volubilis ${ }^{19}$. Niewykluczone więc, że to właśnie Żydzi staliby się pierwszymi chrześcijanami w Afyce Północnej. O dobrych relacjach między chrześcijanami a Żydami w Afryce Północnej świadczą odkryte nekropolie żydowskie w Djebel Khaoui położonej w Gamarth, kilka kilometrów na północ od Kartaginy ${ }^{20}$, i w Oea (dzisiejszym Trypolisie). Uczeni, analizując znalezione tam artefakty, podkreślają, że niekiedy trudno jest jednoznacznie rozstrzygnąć, czy dana inskrypcja ma charakter żydowski czy chrześcijański ${ }^{21}$. W niektórych przypadkach mamy bowiem do czynienia z wyraźnym synkretyzmem religijnym, np. łączenie znaku krzyża z menorą - prawdopodobnie symbol judeochrześcijan. Oprócz grobów typowo żydowskich odkryto tam jedną inskrypcję nagrobną i kilka fragmentów in-

15 Por. C. Aziza, Tertullian et le judaïsme, Nice 1977.

16 Por. B. Blumenkranz, Augustin et les Juifs, „Recherches augustiniennes” 1 (1958) s. 225-241; B. Blumenkranz, Juifs et chrétiens dans le monde occidental. 4301096, Leuven 1960; P. Fredriksen, Augustine and the Jews: A Christian Defense of Jews and Judaism, New York 2008.

17 Por. A. Linder, La loi romaine et les Juifs d'Afrique du Nord, w: Juifs et judaïsme en Afrique du Nord, red. C. Iancu - J.M. Lassère, Montpellier 1987, s. 57-64; A.M. Rabello, Justinian and the Revision of Jewish Legal Status, w: The Cambridge History of Judaism, t. 4, red. S. Katz, Cambridge 2006, s. 1073-1076.

18 Por. J. Lund, A Synagogue at Carthage? Menorah-lamps from the Danish excavations, „Journal of Roman Archeology” 8 (1995) s. 245-262.

19 Por. E. Frézouls, Une synagogue juive attestée à Volubilis, w: Acta of the Fifth International Conference of Greek and Latin Epigraphy, Cambridge 1971, s. 287-293; Y. Le Bohec, Les sources archéologiques du judaïsme africain, w: Juifs et judaïsme en Afrique du Nord, red. C. Iancu - J.M. Lassère, Montpellier 1987, s. 13-47.

20 Por. A.L. Delattre, Gamart ou nécropole juive de Carthage, Lyon 1895.

21 Por. Y. Le Bohec, Inscriptions juives et judaïsantes de l'Afrique romaine, „Antiquités africaines” 17 (1981) s. 165-207; K.B. Stern, Inscribing Devotion and Death: Archeological Evidence for Jewish Populations of North Africa, Leiden - Boston 2007, s. 99-156. 
skrypcji wyraźnie chrześcijańskich. Można więc przypuszczać, że niektórzy chrześcijanie z Afryki Północnej, zapewne pochodzenia żydowskiego, nadal utrzymywali dobre stosunki z synagogą i zostali pochowani niedaleko swoich współziomków żydowskich ${ }^{22}$. W każdym razie od początku III wieku po Chrystusie obecność żydowska jest poświadczona przez znaleziska archeologiczne (inskrypcje z żydowskimi imionami, symbolami i przymiotnikiem Iudaeus, lampki dekorowane menora) od Trypolitanii na wschodzie po wybrzeże Oceanu Atlantyckiego na zachodzie.

To początkowo harmonijne, jak się wydaje, współistnienie dwóch wspólnot w Afryce Północnej zostało zakłócone prawdopodobnie z jednej strony przez rozwijający się prozelityzm żydowski²3, z drugiej zaś przez szybki rozwój Kościoła w drugiej połowie II wieku i pierwszej III wieku ${ }^{24}$. Tertullian w Apologetyku pisał o synagogach jako ,źródle prześladowań" chrześcijan, a jako powód napisania dzieła Adversus Judaeos zaraz na początku przywołuje dysputę pewnego chrześcijanina z Żydem prozelitą, która trwała cały dzień bez widocznego efektu ${ }^{25}$. Pojawiło się w tym czasie wiele wzajemnych oskrażeń i agresji. Tertulian, wzorując się na Nowym Testamencie, Liście Barnaby i Dialogu z Żydem Tryfonem Justyna, przygotowuje więc bardziej systematczną krytykę judaizmu i Żydów oraz obronę wiary chrześcijańskiej. Obecność wspólnoty żydowskiej w Kartaginie pojawia się też w tle innych dzieł Tertuliana. Dwukrotnie przytoczony jest przykład bestiariusa z kartagińskiego cyrku, Żyda-apostaty, który obnosił po mieście figurę osła z podpisem Deus christianorum onocoetes ('ośli Bóg chrześcijan'). Tertulian widzi w synagodze wylęgarnię wszelkich antychrześcijańskich potwarzy (Ad nationes I 14), określa Żydów jako wrogów szczególnych, bo niejako

22 Por. W.H.C. Frend, Jews and Christians in Third Century Carthage, w: Paganisme, Judaisme, Christianisme. Influences et affrontements dans le monde antique, Paris 1978, s. 185-194; C. Setzer, Jews, Jewish Christians and Judaizers in North Africa, w: Putting Body and Soul Together, red. V. Wiles - A. Brown - G.F. Snyder, Valley Forge 1997, s. 185-200.

23 Por. M. Goodman, Mission and Conversion. Proselytizing in the Religious History of the Roman Empire, Oxford 1994; W.G. Braude, Jewish Proselyting in the First Five Centuries of the Common Era: The Age of the Tannaim and Amoraim, Providence 1940; Adamiak, Żydzi w Rzymskiej Afryce Pótnocnej, s. 97-113.

24 Por F. Decret, Early Christianity in North Africa, Cambridge 2011, s. 30-31.

25 Tertulian, Przeciw Żydom I 1, 182: „Niedawno właśnie odbyła się rozmowa chrześcijanina z Żydem, prozelitą. Obydwaj, ciągnąc linę raz po raz, przeciągnęli tak aż do wieczora. I choć włączyli się niektórzy tak z jednej jak i z drugiej strony, to jednak prawdę przysłonięto chmurą. Wydało się więc słuszne aby to, co zostało powiedziane mniej jasno, wyjaśnić przez staranniejsze rozpatrzenie i roztrząsanie zagadnienia i zakończyć w formie pisemnej”. 
„domowych” żołnierzy najemnych (Apologetyk VII 3). Kilkadziesiąt lat później Cyprian widzi w Żydach współodpowiedzialnych razem z poganami za prześladowanie chrześcijan w 250 roku $(E p .59,2)$. Tertulian przekazuje nam też informacje o języku Żydów afrykańskich. Według niego zbierają się co sobota, by czytać Biblię „,w swoim języku” - chodzi tu więc chyba o hebrajski, nie aramejski (Apologetyk VII 3). Wspomina też, że kartagińscy Żydzi określali chrześcijan mianem „nazareńczyków” (Adverus Marcionem IV 8, 1). W IV i V wieku mamy coraz więcej świadectw aktywności żydowskiej w pismach Augustyna, w V wieku biskup Ascellus z Thusurus (Tozeur) skarżył się na chrześcijan, którzy chcieli żyć według Prawa Mojżeszowego i nazywać się Żydami. Z kodeksu Teodozjusza znamy historię słynnych caelicolae (księga VIII), którzy czerpali inspiracje zarówno $\mathrm{z}$ chrześcijaństwa, jak też judaizmu, a może nawet z pogaństwa (niektórzy uważają, że ich kult pochodzi od bogini Caelestis-Tanis). Wydaje się jednak, że sytuacji z IV lub V wieku nie można przenosić na połowę III wieku. Jaka więc była relacja między chrześcijanami i Żydami w Kartaginie w połowie III wieku? Stanowili oni zagrożenie dla wiary chrześcijańskiej? Ich prozelityzm był groźny dla chrześcijan? Pytania te są bardzo ważne, gdyż od odpowiedzi na nie zależy sposób rozumienia dzieła Cypriana. Jeśli stanowili oni realne zagrożenie dla wiary chrześcijańskiej, wtedy Ad Quirinum trzeba rozumieć jako traktat antyżydowski broniący wiary chrześcijan przed intensywnym prozelityzmem żydowskim. Jeśli zaś nie, dzieło Cypriana wpisywałoby się w ogólnochrześcijańską kliszę antyżydowską z II i III wieku bez wyraźnego uzasadnienia. Albo, i to byłoby trzecie wyjaśnienie, traktat byłby skierowany przeciw judeo-chrześcijanom, czyli chrześcijanom pochodzenia żydowskiego, którzy po pierwszym zachwycie nauką chrześcijańską ciążyli coraz bardziej ku zwyczajom żydowskim, wciągając w to również etnochrześcijan. Kwiriniusz prosił Cypriana o wprowadzenie w chrześcijańskie rozumienie Pisma Swiętego. Cyprian przytacza więc w pierwszej księdze teksty biblijne zapowiadające charakter czasowy judaizmu, w drugiej zaś teksty za Jezusem jako obiecanym Mesjaszem. Można by więc przypuszczać, że bezpośredni kontekst powstania dzieła jest raczej egzegetyczny niż antyżydowski. Dlaczego jednak Cyprian przytacza tak wiele teksów przeciw Żydom? Czy nie wystarczyło w kilku zdaniach powiedzieć, że obietnice dane przez Boga Żydom teraz przeszły na chrześcijan, jak to zostało zapowiedziane przez proroków, i następnie przejść szybko do wykazania, że Jezus jest obiecanym Mesjaszem? Albo sam Kwiriniusz, albo wierni kościoła kartagińskiego potrzebowali takiego szerszego uzasadnienia. Być może sam Kwiriniusz był pochodzenia żydowskiego i potrzebował konkretnych argumentów dla swojej 
nowej wiary chrześcijańskiej albo prosił Cypriana o narzędzie do dyskusji z prozelitami żydowskimi lub judeochrześcijanami w Kościele kartagińskim, którzy akcentowali bardzo mocno zwyczaje judaistyczne. Stern wykazała w swojej pracy, że diaspora żydowska w Afryce Północnej była dosyć silna w IV wieku i później ${ }^{26}$, pytanie jednak, czy tak było również w III wieku, pozostaje otwarte. Nie przekonuje interpretacja tych badaczy, którzy widzą w traktacie Cypriana kolejny dowód na antysemityzm wczesnochrześcijański. Wydaje się, że za tego typu tekstami musiała stać konkretna racja lub powód, wyjaśnienie zaś wszystkiego ogólną chrześcijańską niechęcią do Żydów nie przekonuje. Zarówno Adversus Iudaeos Tertuliana, jak też Ad Quirinum Cypriana wpisuje się najprawdopodobniej w realną sytaucję konfliktu albo przynajmniej współzawodnictwa pomiędzy chrześcijanami a wyznawcami judaizmu w Afryce Prokonsularnej pod koniec II i w pierwszej połowie III wieku. Wiązało się to zapewne ze wzrostem liczebnym zarówno jednej, jak i drugiej wspólnoty. Reakcja strony chrześcijańskiej wskazuje na to, iż postrzegali oni wzrost aktywności prozelitów żydowskich jako zagrożenie dla swojej wiary. Nie oznacza to oczywiście, że w miarę przyjazne dotychczas relacje pomiędzy chrześcijanami i Żydami w tym rejonie stały się w III wieku całkowicie nieprzyjazne i konfliktowe. Zapewne byli tam ciągle chrześcijanie pochodzenia żydowskiego, którzy nadal utrzymywali przejazne relacje z etnochrześcijanami, ale też i tacy Żydzi, którzy starali się przekonać pogan albo chrześcijan do judaizmu. Postrzeganie życia tylko w czarno-białych kolorach jest zazwyczaj złudne. Bogatej rzeczywistości relacji chrześcijańsko-żydowskich w Afryce Północnej w III wieku nie da się zamknąć w schemat: relacje przyjazne albo konflikt, polemika lub wzajemne zwalczanie się. Było pewnie i jedno, i drugie.

Wygląda więc na to, że dzieło Cyrpiana wpisuje się w sytuację rosnącego zagrożenia, przynajmniej w subiektywnym odczuciu, dla wiary chrześcijan w Karatginie i okolicach w pierwszej połowie III wieku ze strony prozelityzmu żydowskiego. Nie da się rozstrzygnąć, czy to zagrożenie było realne czy nie, ale z pewnością było postrzegane jako realne przez Tertuliana i Cypriana. Traktat Ad Quirinum nie byłby więc tylko kolejnym dowodem literackim na rosnący antysemityzm wczesnochrześcijański, ale świadkiem realnego napięcia w kontaktach pomiędzy chrześcijanami a Żydami w Afryce Prokonsularnej w połowie III wieku.

26 Por. K.B. Stern, Inscribing Devotion and Death: Archeological Evidence for Jewish Populations of North Africa, Leiden - Boston 2007, s. 51-97. 


\section{Polemic with Jews and Judaism in Ad Quirinum (liber primus) by Cyprian of Carthage}

(summary)

The article presents a short description of the text as a collection of biblical quotes focused on such topics as Mosaic Law (Book I), Christology (Book II) and Christian virtues (Book III) and also comments on the version of the biblical text that Cyprian cites. A survey of comparative studies showed that the biblical text cited by Cyprian departs from the Jerome's Vulgate. Secondly, Cyprian's writing is an autonomous treatise independent of Adversus Iudaeos of Tertullian, written at the request of Quirinus, who aimed to provide the addressee and other Christians in Carthage tools in the form of biblical passages to fight the growing Jewish proselytism. As for the historical context of its creation, the treaty is part of the middle of the third century. Previous good relations between Christians and Jews in North Africa, as evidenced by even Jewish necropolises with Christian graves or inscriptions with a cross and a menorah, are beginning to be broken due to the growing Jewish proselytism and the growth of the Christian community.

Keywords: Cyprian of Carthage; Testimonia; Ad Quirinium

\section{Polemika z Żydami i judaizmem w Ad Quirinum (liber primus) Cypriana z Kartaginy}

(streszczenie)

Artykuł przedstawia krótki opis dzieła jako zbioru tekstów biblijnych skupionych wokół następujących tematów: Prawo Mojżeszowe (ksiega I), chrystologia (księga II) i cnoty chrześcijańskie (księga III), a także ocenę wersji tekstu biblijnego, który Cyprian cytuje. Sondażowe badanie porównawcze pokazało, że Cyprian używał innej wersji tekstu biblijnego niż ta, która później stała się częścią Wulgaty Hieronima. Po drugie, dzieło Cypriana jest samodzielnym traktatem, niezależnym od Adversus Iudaeos Tertuliana, napisanym na prośbę Kwiriniusza, który stawiał sobie za cel dostarczyć adresatowi i innym chrześcijanom kartagińskim narzędzia w postaci tekstów biblijnych użytecznych w polemice z wzrastajacym prozelityzmem żydowskim. Pismo dobrze wpisuje się w kontekst historyczny połowy III wieku, kiedy to wcześniejsze dobre relacje pomiędzy chrześcijanami a Żydami w Afryce Północnej, jak to potwierdzają groby chrześcijańskie odkryte w nekropoliach żydowskich albo inskypcje łączące krzyż i menorę, zaczynają się psuć z powodu rosnącego prozelityzmu żydowskiego i jednocześnie wzrostu wspólnoty chrześcijańśkiej.

Słowa kluczowe: Cyprian z Kartaginy; Testimonia; Do Kwiriniusza 


\section{Bibliografia}

\section{Źródła}

Cyprianus, Ad Quirinum, (Testimoniorum lobri tres), ed. W. Hartl, CSEL 3/1, Vindobonae 1868, s. 33-184, tt. J. Czuj, Tascjusza Cecyliusza Cypriana, „Do Kwiryna” (Świadectw trzy księgi), POK 19, Poznań 1937, s. 113-134.

Tertullianus, Adverus Iudaeos, ed. A. Gerlo et al., CCSL 33, Turnhoult 1954, s. 13371396, tt. W. Myszor, Przeciw Żydom, w: Tertulian, Wybór pism II, PSP 29, Warszawa 1983, s. $182-218$.

\section{Opracowania}

Adamiak S., Żydzi w Rzymskiej Afryce Pótnocnej, „Biblica et Patristica Thoruniensia” 7 (2014) s. 97-113.

Albl M.Ch., „And Scripture cannot Be Broken”. Function of the Early Christians Testimonial Collections. NTSup 96, Leiden 1999.

Audet J.P., L'Hypothese des Testimonia, „Revue Biblique” 70 (1963) s. 381-405.

Aziza C., Tertullian et le judaïsme, Nice 1977.

Blumenkranz B., Augustin et les Juifs, „Recherches augustiniennes” 1 (1958) s. 225-241. Blumenkranz B., Juifs et chrétiens dans le monde occidental. 430-1096, Leuven 1960.

Braude W.G., Jewish Proselyting in the First Five Centuries of the Common Era: The Age of the Tannaim and Amoraim, Providence 1940.

Camps G., Réflexions sur l'origine des Juifs des régions nord-sahariennes, w: Communautés juives des marges sahariennes du Maghreb, ed. M. Abitbol, Paris 1982, s. 57-67.

Chadwick H., Justin Martyr's Defence of Christianity, „John Ryands Library” 47 (1965) s. 275-297.

Decret F., Early Christianity in North Africa, Cambridge 2011.

Delattre A.L., Gamart ou nécropole juive de Carthage, Lyon 1895.

Ferri R., Regional Differentiation and the Old Latin Bible?, „Linguarum Varietas” 6 (2017) s. 255-261.

Frederikson P., Augustine and the Jews: A Christian Defense of Jews and Judaism, New York 2008.

Frend W.H.C., Jews and Christians in Third Century Carthage, w: Paganisme, Judaisme, Christianisme. Influences et affrontements dans le monde antique, Paris 1978.

Frezouls E., Une synagogue juive attestée à Volubilis, w: Acta of the Fifth International Conference of Greek and Latin Epigraphy, Cambridge 1971, s. 287-293.

Gebbia C., Le comunità giudaica nell'Africa romana antica e tardoantica, „L'Africa Romana" 3 (1986) s. 101-112. 
Goodman M., Mission and Conversion. Proselytizing in the Religious History of the Roman Empire, Oxford 1994.

Hadas-Lebel M., Les juifs en Afrique romaine, w: Questions d'histoire. L'Afrique romaine de 69 à 439. Romanisation et christianisation, red. B. Cabouret, Nantes 2005, s. 325-334.

Hirschenberg W.Z., A History of Jews in North Africa. I. From Antiquity to the Sixteenth Century, Leyde 1974.

Horbury W., Jewish and Christian Origins in Roman Africa, w: The Rise and Expansion of Christianity in the First Three Centuries of the Common Era, red. C.K. Rotschild J. Schröter, Tübingen 2013, s. 51-69.

Hougton H.A.G., The Latin New Testament: A Guide to its Early History, Text and Manuscripts, Oxford 2016.

Kedar B., The Latin Translations, „Mikra” (1988) s. 299-338.

Le Bohec Y., Les sources archéologiques du judaïsme africain, w: Juifs et judaïsme en Afrique du Nord, red. C. Iancu - J.M. Lassère, Montpellier 1987, s. 13-47.

Le Bohec Y., Inscriptions juives et judaïsantes de l'Afrique romaine, „Antiquités africaines" 17 (1981) s. 165-207.

Linder A., La loi romaine et les Juifs d'Afrique du Nord, w: Juifs et judä̈sme en Afrique $d u$ Nord, red. C. Iancu - J.M. Lassère, Montpellier 1987, s. 57-64.

Lowy S., The Confutation of Judaism in the Epistle of Barnabas, „Journal of Jewish Studies" 11 (1960) s. 1-33.

Kraft A.R., Barnabas' Isaiah Text and ,, The Testimony Book” Hypothesis, „Journal of Biblical Literature" 79 (1960) s. 336-350.

Lund J., A Synagogue at Carthage? Menorah-lamp from the Danish excavations, „Journal of Roman Archeology" 8 (1995) s. 244-262.

Misiarczyk L., Il Midrash nel Dialogo con Trifone di Giustino Martire, Płock 1999.

O'Hagan A., Early Christian Exegesis exemplified from the Epistle of Barnabas, „Australian Biblical Review" 11 (1963) s. 33-40.

Prigent P., Les Testimonia dans le Christianisme primitive. L'Épitre de Barnabé I-XVI et ses source, Paris 1961.

Quasten J., Patrologia, t. 1, Casale Monferrato 1980.

Quispel G., The Discussion fo Judaic-Christianit. Additional Note, „Vetera Christianorum" 22 (1968) s. 81-93.

Rabello A.M., Justinian and the Revision of Jewish Legal Status, w: The Cambridge History of Judaism, t. 4, red. S. Katz, Cambridge 2006, s. 1073-1076.

Rendel Harris J., Testimonies, t. 1-2, Cambridge 1916-1920.

Setzer C., Jews, Jewish Christians and Judaizers in North Africa, w: Putting Body and Soul Together, red. V. Wiles - A. Brown - G.F. Snyder, Valley Forge 1997, s. 185-200.

Stern K.B., Inscribing Devotion and Death: Archeological Evidence for Jewish Populations of North Africa, Leiden - Boston 2007.

Trebolle Barrera J., Lo Christiano e lo Judio en la Vetus Latina, „El Olivo” 15 (1991) s. $123-141$. 